\title{
EFEKTIVITAS BIMBINGAN KELOMPOK DENGAN TEKNIK DISKUSI UNTUK MENINGKATKAN KEMANDIRIAN BELAJAR SISWA KELAS VII DI SMP IT MASJID SYUHADA YOGYAKARTA
}

\author{
Tri Susilo ${ }^{1}$, Drajat Edy Kurniawan ${ }^{2}$ \\ Universitas PGRI Yogyakarta \\ Email : drajat@upy.ac.id
}

\begin{tabular}{|c|c|}
\hline Article Info & \\
\hline $\begin{array}{l}\text { Available online } \\
15.06 .2020\end{array}$ & $\begin{array}{l}\text { Tujuan penelitian ini adalah untuk mengetahui apakah layanan bimbingan kelompok } \\
\text { dengan teknikDiskusi efektif untuk meningkatkan kemandirian belajar siswa kelas VII di SMP } \\
\text { IT Masjid Syuhada Yogyakarta tahun ajaran } 2019 / 2020 \text {. Populasi penelitian ini adalah siswa } \\
\text { kelas VII di SMP IT Masjid Syuhada Yogyakarta tahun pelajaran } 2019 / 2020 \text { yang berjumlah } \\
123 \text { siswa yang terbagi dalam } 4 \text { kelas. Sampel dalam penelitian diambil sebanyak6 siswa yang } \\
\text { memiliki tingkat kemandirian belajar rendah dengan menggunakan teknik purposive } \\
\text { sampling. Metode pengumpulan data dalam penelitian ini dengan menggunakan pedoman } \\
\text { observasi, pedoman wawancara dan angket. Teknik analisis data dengan menggunakan } \\
\text { statistik dengan rumus uji t-tes. Hasil penelitian menunjukkan bahwa dari hasil uji t-test } \\
\text { diperoleh nilai t = } 14.556 \text { dengan nilai Sig = 0,000 < 0,05. Oleh karena hipotesis penelitian } \\
\text { terbukti kebenarannya maka kesimpulan penelitian ini yaitu layanan bimbingan kelompok } \\
\text { dengan teknik diskusi efektif untuk untuk meningkatkan kemandirian belajar siswa kelas VII } \\
\text { di SMP IT Masjid Syuhada Yogyakarta tahun ajaran } 2019 / 2020 \text {. } \\
\text { Keyword : bimbingan kelompok, diskusi, kemandirian belajar }\end{array}$ \\
\hline
\end{tabular}

\section{Pendahuluan}

Pendidikan merupakan suatu hal yang penting dan wajib diberikan oleh orang tua kepada individu. Memperoleh pendidikan merupakan hak setiap individu karena pendidikan berperan bagi kelangsungan hidup dan masa depan bagi individu. Pendidikan menjadi salah satu wadah yang digunakan untuk membangun kecerdasan dan membentuk karakter serta mengembangkan segenap potensi yang dimiliki oleh individu. Selain itu, pendidikan memiliki peranan penting dalam meningkatkan kualitas sumber daya manusia.

Didin Kurniadin dan Imam Machali (2014:112) mengemukakan bahwa, pendidikan adalah segala pengalaman belajar yang berlangsung dalam segala lingkungan dan sepanjang hidup. Sedangkan menurut Kompri (2015:15) Pendidikan adalah usaha sadar yang dilakukan orang dewasa atau pendidik dalam menyelenggarakan kegiatan pengembangan diri agar sesuai dengan tujuan yang telah ditentukan sebelumnya. Berdasarkan pendapat tersebut, dapat disimpulkan bahwa pendidikan adalah segala usaha sadar dalam sebuah proses yang diperlukan untuk mendapatkan keseimbangan dan kesempurnaan dalam perkembangan individu atau komunitas nasional.

Pendidikan memiliki berbagai macam tujuan, menurut UU No. 20 Tahun 2003 tentang Sistem Penedidikan Nasional dijelaskan bahwa, pendidikan memiliki tujuan untuk mengembangkan potensi peserta didik agar menjadi manusia yang beriman dan bertakwa 
kepada Tuhan Yang Maha Esa, berakhlak mulia, sehat, berilmu, cakap, kreatif, mandiri dan menjadi warga negara yang demokratis dan bertanggung jawab.Pendapat tersebut bermakna bahwa tujuan pendidikan yaitu mengembangkan segenap potensi yang dimiliki oleh seorang individu untuk menjadi individu yang beriman,cerdas dan tanggung jawab.

Salah satu cara untuk mengembangkan potensi yaitu dengan belajar. Belajar dimulai dengan adanya dorongan, semangat, dan upaya yang timbul dalam diri setiap individu sehingga individu itu melakukan kegiatan belajar. Belajar merupakan sebuah proses kegiatan seseorang yang dilakukan dengan sengaja melalui penyesuaian tingkah laku dirinya dalam upaya meningkatkan kualitas kehidupannya (Abdul Majid, 2013:33). Selanjutnya, Suwardi dan Daryanto (2017:78) menjelaskan bahwa belajar adalah suatu aktivitas latihan untuk memperoleh perubahan tingkah laku sebagai hasil interaksi dengan lingkungan sekitar untuk memenuhi kebutuhan hidupnya. Berdasarkan pendapat tersebut dapat disimpulkan bahwa belajar adalah sebuah proses kegiatan menggali potensi yang dimiliki seseorang untuk memperbaiki kehidupannya.

Kegiatan belajar yang dilakukan menyesuaikan dengan tingkah laku setiap individu dalam upaya meningkatkan kemampuan dan kualitas diri. Dalam hal ini, setiap individu harus memiliki kemandirian belajar dalam hidupnya agar dapat mengembangkan potensinya secara optimal. Salah satu indikator untuk mengembangkan potensi peserta didik secara optimal harus memiliki kemandirian belajar. Kemandirian belajar ditandai dengan memiliki kesadaran diri, tanggung jawab, memiliki tujuan, memiliki inisiatif, tidak tergantung dengan orang lain dan percaya diri, alangkah lebih bagus siswa dapat belajar secara mandiri dan berusaha untuk dapat mengevaluasi kembali hasil belajar yang telah didapatkan di sekolah, hal ini dapat membantu siswa dalam memperdalam ilmu pengetahuan dan meningkatkan prestasi belajarnya, hal itu disebut dengan kemandirian belajar siswa.

Kaitanya dengan kemandirian belajar Haris Mujiman (2011:1) mengemukakan bahwa, kemandirian belajar adalah kegiatan belajar aktif yang didorong oleh niat dan motif untuk menguasai kompetensi guna mengatasi suatu masalah, dan dibangun dengan bekal pengetahuan atau kompetensi yang dimiliki.Kemandirian belajar mendorong siswa untuk aktif dalam kegiatan belajarnya,melatih tanggung jawab terhadap kegiatan yang dilakukan, dan siswa mampu memecahkan masalah dan mengatasinya sendiri.

Sementara itu, Rostina Sundayana (2016: 78) menjelaskan bahwa, kemandirian belajar adalah suatu proses belajar dimana setiap individu dapat mengambil inisiatif, dengan atau tanpa bantuan orang lain, dalam hal menentukan kegiatan belajarnya seperti merumuskan 
tujuan belajar, sumber belajar (baik berupa orang ataupun bahan), mendiagnosa kebutuhan belajar, mengontrol dan bertanggung jawab sendiri proses pembelajarannya. Mengacu pada kedua pendapat terebut maka, kemandirian belajar adalah aktivitas belajar dengan inisiatif dan kemauan sendiri untuk menguasai dan menentukan sendiri proses pembelajaran.

Kemandirian belajar perlu dimiliki setiap individu agar memiliki tanggung jawab dalam mengatur dan mendisiplinkan diri. Selain itu, dalam mengembangkan kemampuan diri, sikapsikap tersebut perlu dimiliki oleh individu sebagai ciri dari kedewasaan individu. Pada hakikatnya, kemandirian belajar seorang individu perlu ditumbuhkan pada diri peserta didik, hal tersebut bertujuan agar individu mampu memecahkan dan mengerjakan segala sesuatu sesuai dengan kemampuan diri, tanpa tergantung pada orang lain. Individu yang memiliki kemandirian belajar yang tinggi akan berusaha menyelesaikan tugas yang diberikan guru sesuai dengan kemampuan yang dimiliki. Sebaliknya individu yang memiliki kemandirian belajar rendah akan cenderung bergantung orang lain.

Membahas mengenai kemandirian belajar, individu diharapkan mampu bertanggung jawab, disiplin, percaya diri dan tidak bergantung pada orang lain dalam belajar. Hal tersebut bertujuan agarindividu mampu menyelesaikan pekerjaan secara mandiri. Selain itu individu dapat mencapai prestasi belajar yang baik dan memuaskan. Terdapat beberapa manfaat kemandirian belajar. Menurut Imam Mashuri (2012:24), kemandirian belajar siswa memiliki manfaat terhadap kemampuan kognisi, afeksi, dan psikomotorik siswa. Beberapa manfaat tersebut diantaranya yaitu memupuk tanggung jawab, meningkatkan keterampilan, memecahkan masalah, mengambil keputusan, berpikir kreatif, berpikir kritis, percaya diri yang kuat, serta menjadi guru bagi diri sendiri.

Namun, realita yang terjadi yaitutidak semua siswa memiliki kemandirian belajar yang tinggi. Hal tersebut dapat di buktikan berdasarkan data yang diperoleh peneliti dilapangan. Realita dilapangan menunjukan bahwa di SMP IT Masjid Syuhada Yogyakarta khususnya kelas VII masih terdapat individu yang memiliki tingkat kemandirian belajar yang rendah, Hasil observasi peneliti membuktikan bahwa masih banyak siswa yang berada diluar kelas pada saat pergantian jam pelajaran. Kondisi tersebut dapat dimaknai bahwa individu kurang memiliki kesadaran untuk melaksanakan kegiatan belajar. Selain itu peneliti menemukan data yaitu masih ada anak yang menyontek pada saat ujian, tidak mengumpulkan tugas tepat waktu atau menyalin pekerjaan teman, serta minimnya minat baca siswa

Rendahnya kemandirian belajar siswa perlu mendapatkan perhatian yang serius dari sekolah. Bimbingan dan Konseling sebagai bagian integral di sekolah berperan penting dalam 
mengatasi permasalahan tersebut. Terdapat beberapa upaya yang sudah dilakukan Guru BK untuk meningkatkan kemandiria belajar siswa. Salah satu upaya yang sudah dilakukan yaitu dengan menerapkan layanan bimbingan konseling seperti layanan klasikal di dalam kelas.Akan tetapi upaya tersebut kurang berhasil karena masih banyaknya siswa yang meliliki kemandirian belajar rendah.

Berdasarkan permasalahan tersebut, maka peneliti tertarik untuk mencari strategi atau upaya lain yang tepat untuk meningkatkan kemandirian belajar siswa. Salah satu upaya yang dapat dilakukan yaitu dengan menerapkan layanan Bimbingan Kelompok dengan teknik diskusi. Kaitanya dengan bimbingan kelompok Winkel dan Sri Hastuti (2013:545) menjelaskan bahwa, bimbingan kelompok merupakan satuan/unit orang yang memiliki tujuan yang ingin dicapai bersama, berinteraksi dan berkomunikasi secara intensif satu sama lain pada waktu berkumpul, saling tergantung dalam proses bekerja sama, dan mendapatkan kepuasan pribadi dari interaksi psikologis dengan seluruh anggota yang tergabung dalam satuan. Senada pendapat tersebut Tatiek Romlah (2006:3) mengemukakan bahwa, bimbingan kelompok merupakan proses pemberian bantuan kepada individu dalam situasi kelompok. Lebih lanjut bimbingan kelompok ditujukan untuk mencegah munculnya masalah pada siswa dan mengembangkan potensi siswa. Berdasarkan pendapat tersebut maka bahwa bimbingan kelompok merupakan proses pemberian informasi dan bantuan yang diberikan oleh seorang yang ahli pada sekelompok orang dengan memanfaatkan dinamika kelompok untuk mencapai suatu tujuan tertentu.

Salah satu teknik dalam bimbingan kelompok yaitu teknik diskusi.Abdul Majid (2013:200) menegaskan bahwa, teknik diskusi adalah metode pembelajaran yang menghadapkan siswa pada suatu permasalahan.Tujuan teknik tersebut adalah untuk memecahkan suatu permasalahan, menjawab suatu pertanyaan, menambahkan dan memahami pengetahuan siswa.Sementara itu Don Kauchak dan Paul Eggen (2012:154) mengemukakan bahwa, teknik diskusi adalah strategi instruksional atau pengajaran yang melibatkan siswa untuk berbagai ide tentang satu topik umum.Sehingga, teknik diskusi adalah teknik yang dilaksanakan dengan maksud agar para siswa atau anggota kelompok mendapat kesempatan untuk memecahkan masalah secara bersama-sama melalui diskusi kelompok.

Melalui teknik diskusi, siswa diharapkan mampu bertukar pendapat, memberi dan menerima masukan orang lain, serta belajar secara mandiri. Oleh karena itu dapat dipastikan kemandirian belajar siswa akan meningkat. Mengacu pada uraian tersebutmaka peneliti tertarik untuk melakukan penelitian dengan judul Efektifitas layanan bimbingan kelompok 
dengan teknik diskusi untuk meningkatkan kemandirian belajar siswa kelas VII SMPIT Masjid Syuhada Yogyakarta tahun ajaran 2019/2020.

\section{Metode Penelitian}

\section{Waktu dan Tempat Penelitian}

Penelitian ini dilaksanakan mulai bulan Mei sampai dengan bulan Desember 2019. Penelitian ini dilaksanakan di SMP IT Masjid Syuhada Yogyakarta. Alasan peneliti dalam menentukan tempat penelitian yaitu, karena di sekolah tersebut terdapat permasalahan mengenai kemandirian belajar siswa yang masih rendah.

\section{Metode, Jenis dan Desain Penelitian}

Metode penelitian yang digunakan dalam penelitian ini adalah metode penelitian kuantitatif. Metode penelitian kuantitatif adalah Menurut Sugiyono (2016:13) yang dimaksud dengan penelitian kuantitatif adalah metode penelitian yang berlandaskan pada filsafat positivism, digunakan untuk meneliti pada populasi atau sampel tertentu, teknik pengambilan sampel pada umumnya dilakukan secara random, pengumpulan data menggunakan instrument penelitian, analisis data bersifat kuantitatif/statistik dengan tujuan untuk menguji hipotesis yang telah ditetapkan. Jenis penelitian yang digunakan dalam penelitian ini adalah penelitian eksperimen. Menurut Suharsimi Arikunto (2010: 9) eksperimen adalah suatu cara untuk mencari hubungan sebab akibat (hubungan kausal) antara dua faktor yang sengaja ditimbulkan oleh peneliti dengan mengeliminasi atau mengurangi atau menyisihkan faktor-faktor lain yang menggangu. Sementara itu, desain eksperimen yang digunakan dalam penelitian ini adalah adalah pre experimental design dengan One-Group Pretest-Posttest Design yaitu dengan cara memberikan perlakuan terhadap satu kelompok eksperimen dengan melakukan layanan bimbingan kelompok dengan menggunakan teknik diskusi.

\section{Subyek Penelitian}

Populasi dalam penelitian ini yaitu seluruh siswa kelas VII SMPIT Masjid Syuhada Yogyakarta yang berjumlah 123 siswa. Selanjutnya, sampel dalam penelitian ini yaitu siswa yang tergolong memiliki tingkat kemandirian belajar rendah. Sementara itu, teknik sampling dalam penelitian ini yaitu teknik sampling bertujuan atau purposive sample. Alasan peneliti menggunakan teknik sampling ini yaitu dalam memilih sample, peneliti memilih sample berdasarkan tingkat kemandirian belajar siswa.Hal tersebut dikarenakan penelitian ini bertujuan untuk meningkatkan kemandirian belajar siswa, maka teknik purposive sampling bertujuan untuk memperoleh siswa dengan tingkat kemandirian belajar yang rendah. 


\section{Variabel Penelitian}

Variabel merupakan salah satu komponen penting dalam suatu penelitian. Menururt Sugiyono (2013:60) variabel penelitian pada dasarnya adalah segala sesuatu yang ditetapkan oleh peneliti untuk dipelajari sehingga diperoleh informasi tentang hal tersebut, untuk ditarik sebuah kesimpulan. Penelitian ini memilik dua variable yaitu variabel bebas dan variabel terikat. Variable bebas dalam penelitian ini yaitu layanan bimbingan kelompok dengan teknik diskusi. Sementara itu, variabel terikat dalam penelitian ini yaitu kemandirian belajar siswa.

\section{Teknik dan Instrumen Pengumpulan Data}

Teknik pengumpulan data adalah cara yang digunakan untuk mengumpulkan serangkaian data dengan prinsip-prinsip dan alat-alat tertentu. Menurut Sugiyono (2013:224) teknik pengumpulan data yaitu langkah yang paling strategis dalam penelitian, karena tujuan utama dari penelitian adalah mendapatkan data. Teknik pengumpulan data dalam penelitian ini yaitu teknik angket. Sementara itu, instrument pengumpulan data dalam penelitian ini yaitu instrumen angket.

\section{Uji Validitas dan Reliabilitas Instrumen}

Penghitungan uji validitas instrumen dalam penelitian ini dibantu dengan program IBM SPSS Statistik 24. Masing-masing item angket dapat dikatakan valid apabila nilai Rxy > 0,3 ( Azwar, 2009 : 65 ). Sehingga dalam penelitian ini kriteria item angket dikatakan valid apabila Rxy $>0,3$. Sementara itu, untuk uji analisis reliabilitas instrumen menggunakan penghitungan koefisien Cronbach's alpha dengan bantuan program IBM SPSS Statistik 24. Sunarti dan Selly (2014: 99) mengemukakan bahwa, batas minimal Cronbach's alpha adalah 0,70. Dengan kata lain apabila koefisien cronbach's alpha $\geq 0,70$ akan dapat dikatakan bahwa instrumen pengukuran dalam penelitian ini dinyatakan reliable.

\section{Teknik Analisis Data}

\section{Uji Normalitas}

Uji normalitas data merupakan syarat yang harus dipenuhi dalam analisis data. Menurut Edi Riadi (2016: 105) bahwa uji asumsi normalitas yang lebih kompleks dan lengkap dimaksudkan untuk menguji apakah model yang diusulkan memiliki kesesuaian dengan data atau tidak. Uji normalitas dimaksudkan untuk mengetahui apakah data hasil penelitian berdistribusi normal atau tidak. Perhitungan uji normalitas dilakukan dengan menggunakan one sample kolmogorov smirnov dengan bantuan IBM SPSS Statistik 24. Data dinyatakan berdistribusi normal apabila nilai signifikansi lebih dari >0.05. Edi Riadi (2016: 112).

\section{Uji Homogenitas}

Uji homogenitas digunakan untuk menguji apakah sebaran data dari dua varian atau lebih berasal dari populasi yang homogen atau tidak, yaitu dengan membandingkan dua atau lebih 
variannya (Edi Riadi, 2016 127). Perhitungan uji homogenitas ini dilakukan sebagai prasyarat dalam uji hipoteis, yaitu One Way Anove dengan bantuan IBM SPSS Statistik 24. Data dinyatakan homogen apabila nilai signifikansi lebih dari >0.05. (Edi Riadi ,2016: 140).

\section{Uji-t}

Uji-t yang digunakan dalam penelitian ini yaitu menggunakan Uji Paired Sample Test. Paired Sample Test berfungsi untuk mengetahui apakah ada perbedaan dua rata-rata atau lebih untuk sampel yang berpasangan sekaligus dapat mengetahui apakah pebedaan tersebut signifikan atau tidak (Edi Riadi, 2016: 15). Perhitungan ujiPaired SampleTest dilakukan dengan bantuan IBM SPSS Statistik 24. Cara pengambilan kesimpulan hasil uji Hipotesis adalah apabila nilai signifikansi $>0,05$, maka tidak ada perbedaan rerata antara skor pretes dengan skor postes dan apabila nilai signifikansi $<0,05$, maka ada perbedaan rerata antara skor pretes dengan skor postes.

Sehingga treatment perlakuan dinyatakan efektif apabila terdapat perbedaan rerata antara skor pretes dengan skor postes.

\section{Hasil dan Pembahasan}

Kegiatan layanan bimbingan kelompok merupakan suatu layanan yang dilakukan dengan beberapa siswa, yang diberikan dalam suasana kelompok. Bimbingan kelompok berfokus dalam menyelesaikan masalah individu namun dilakukan dalam suatu kelompok untuk memberikan kemudahan kepada siswa dalam membantu pertumbuhan dan perkembangan diri individu. Sehingga peneliti menggunakan layanan bimbingan kelompok dengan teknik diskusi. Kegiatan pemberian layanan ini dilaksanakan di SMP IT Masjid Syuhada Yogyakarta, dilakukan sebanyak 1 kali penyebaran angket pretest, 3 kali pertemuan dalam pemberian layanan bimbingan kelompok dan 1 kali pengisian angket posttest. Dari 82 peserta didik yang berada dikelas VII terdapat 6 siswa yang termasuk kategori kemandirian belajar rendah, sesuai dengan tabel kategori kemandirian belajar dan hal ini diketahui dengan dilihatnya hasil skor pretest yang termasuk kategori rendah.

Penggunaan layanan bimbingan kelompok dengan teknik diskusi untuk meningkatkan kemandirian belajar siswa dengan alasan bahwa penggunaan teknik diskusi dalam bimbingan kelompok dapat membuat siswa menjadi lebih aktif, karena bisa menciptakan dinamika dalam suatu kelompok. Dinamika yang tercipta di dalam kelompok tersebut membuat siswa bisa mengungkapkan pendapat mereka dalam permasalahan yang sedang dihadapinya yaitu perihal motivasi belajar, dengan adanya pendapat masing-masing bisa membantu kelompoknya dalam 
mengatasi permasalahan yang dihadapinya, siswa yang semulanya kurang memiliki kemandirian belajar jadi memiliki kemandirian belajar yang tinggi.

Berdasarkan hasil penyebaran angket yang diberikan kepada 82 siswa, dapat diketahui bahwa sebelum diberikan layanan bimbingan kelompok dengan teknik diskusi, terdapat 6 siswa yang masuk dalam kategori rendah. Hal ini menunjukkan bahwa secara umum siswa memiliki tingkat kemandirian belajar rendah, dan hasil ini didapat dari hasil pretest sehingga siswa perlu mendapatkan perlakuan lebih lanjut. Setelah 6 sampel tersebut mendapatkan perlakuan (treatment) berupa layanan bimbingan kelompok dengan teknik diskusi, ternyata terjadi perubahan dari siswa yang memiliki kemandirian belajar dengan kategori rendah dengan mengalami kenaikan, yaitu dilihat dari perubahan sikap dan tingkah laku siswa pada setiap pemberian treatment dan sebelum diberikan treatment yang memiliki skor rata-rata pre test sebesar 56,33 dan setelah diberikan treatment memiliki skor rata-rata post test sebesar 97,33. Selisih antara angket (kuesioner) tingkat kemandirian belajar siswa setelah dan sebelum treatment sebesar 41,00.

Berdasarkan hasil analisis uji t diperoleh nilai $t=14.556$ dengan nilai $\mathrm{p}=0,000<0,005$. Uji t dengan kriteria $\mathrm{p}<0,005$ maka hipotesis yang diajukan terbukti dan signifikan. Dari hasil penelitian menunjukan bahwa bimbingan kelompok dengan teknikdiskusiefektif untuk meningkatkan kemandirian belajar siswa kelas VII di SMP IT Masjid Syuhada Yogyakarta tahun ajaran 2019/2020. Sejalan dengan penelitian yang dilakukan oleh Putu Nopi Sayondari tahun 2014. Penerapan “Bimbingan Kelompok Dengan Teknik Diskusi Kelompok Untuk Meningkatkan Rasa Percaya Diri Siswa Kelas VIII E SMP Negeri 3 Singaraja Tahun Pelajaran 2013/2014." Penelitian ini bertujuan untuk mengetahui penerapan bimbingan kelompok dengan teknik diskusi kelompok dalam meningkatkan rasa percaya diri siswa kelas VIII E di SMP Negeri 3 Singaraja tahun pelajaran 2013/2014.Hasil penelitian ini menunjukan bahwa penerapan bimbingan kelompok dengan teknik diskusi kelompok dapat digunakan untuk meningkatkan rasa percaya diri siswa kelas VIII E. selanjutnya, Alzachbana tahun 2013. Penerapan "Bimbingan Kelompok Teknik Diskusi Dengan Topik Konsep Diri Untuk Meningkatkan Percaya Diri Siswa Kelas X-7 SMA Negeri 1 Sumenep". Tujuan penelitian ini adalah menguji penerapan bimbingan kelompok teknik diskusi untuk meningkatkan percaya diri siswa kelas X-7 SMA Negeri 1 Sumenep. Peneliti ini merupakan penelitian Pre-Experiment dengan jenis One-Group Pre-Test and Post-test design. Hasil penelitian tersebut yaitu bimbingan kelompok teknik diskusi dengan topik konsep diri dapat digunakan oleh pembimbing untuk meningkatkan percaya diri siswa kelas X-7 SMA Negeri 1 Sumenep.Yuyun 
Lestari tahun 2015. Peningkatan Kemandirian Belajar Dengan Layanan Bimbingan Kelompok. Tujuan penelitian ini untuk meningkatkan kemandirian belajar siswa. Hasil penelitian tersebut menunjukkan bahwa terdapat peningkatan pada kemandirian belajar siswa setelah di berikan layanan bimbingan kelompok.

Selanjutnya Nor Asiyah tahun 2012. "Peranan Layanan Bimbingan Kelompok dalam Meningkatkan Kemandirian Belajar Siswa Kelas VII Mts Nu Miftahul Huda 02 Piji Bakaran Tahun Ajaran 2011/2012".Penelitian ini bertujuan untuk mengetahui penerapan bimbingan kelompok dengan teknik diskusi kelompok dalam meningkatkan kemandirian belajar siswa Kelas VII Mts Nu Miftahul Huda 02 Piji Bakaran Tahun Ajaran 2011/2012. Hasil penelitian tersebut menunjukan bahwa, setelah diberi layanan bimbingan kelompok terdapat peningkatan kemandirian belajar.Berdasarkan beberapa hasil penelitian tersebut, maka dapat disimpulkan bahwa bimbingan kelompok dengan teknik diskusi terbukti efektif digunakan untuk meningkatkan kemandirian belajar siswa kelas VII di SMP IT Masjid Syuhada Yogyakarta Tahun Ajaran 2019/2020.

\section{Kesimpulan dan Saran}

Kesimpulan dalam penelitian ini yaitu layanan bimbingan kelompok dengan teknik diskusi terbukti efektif untuk meningkatkan kemandirian belajar siswa kelas VII di SMP IT Masjid Syuhada Yogyakarta tahun ajaran 2019/2020. Selanjutnya, saran penelitian ini adalah Kepala Sekolah sebaiknya mendukung pelaksanaan layanan bimbingan dan konseling dalam upaya meningkatkan kemandirian belajar siswa melalui peningkatan sarana dan prasarana serta kualitas dalam pelaksanaan program yang memadai, dengan maksud agar hasil yang dicapai bisa lebih maksimal dan tepat sasaran.

Bagi guru Bimbingan dan Konseling diharapkan lebih aktif dalam memberikan layanan bimbingan kelompok, konselor atau guru bimbingan dan konseling juga lebih inovatif dalam memberikan layanan. Dalam memberikan layanan, konselor bisa menggunakan pendekatanpendekatan yang inovatif seperti menggunakan media yang menarik dalam penyampaian layanannya, sehingga siswa menjadi tertarik dan mampu mengaplikasikan materi kemandirian dalam belajar yang disampaikan dalam kehidupan sehari-harinya.

Bagi peneliti selanjutnya, sebaiknya konsep penelitian dan pengkondisian siswa lebih dimatangkan lagi agar tidak terlalu banyak waktu yang terbuang untuk mempersiapkan siswa agar kondusif dan tenang, sehingga pemberian layanan bimbingan kelompok dengan teknik diskusi dapat berjalan secara optimal. 


\section{DAFTAR PUSTAKA}

Abdul Majid. 2013. Strategi Pembelajaran. Bandung: PT Remaja Rosdakarya.

Alzachbana.2013.143. Penerapan Bimbingan Kelompok Teknik Diskusi Dengan Topik Konsep Diri Untuk Meningkatkan Percaya Diri Siswa Kelas X-7 Sma Negeri 1 Sumenep. Jurnal BK UNESA, Volume 03 No 01. file:///C:/Users/user\%20only/Downloads/247314-penerapanbimbingan-kelompok-teknik-disk-dc60aa60.pdf. di unduh pada hari Selasa pukul 13.50 WIB.

Azwar Saifuddin.2009. Metode penelitian. Yogyakarta: Pustaka Belajar.

Didin Kurniadin dan Imam Machali. 2014. Manajemen Pendidikan (Konsep dan Prinsip Pengelolaan Pendidikan). Yogyakarya: Ar-Ruzz Media.

Don Kauchak dan Paul Eggen. 2012. Strategi dan Model Pembelajaran. Jakarta: Pearson Indeks. Edi Riadi. 2016. Statistika Penelitian (Analisis Manual dan SPSS). Yogyakarta: CV Andi Offet.

Huri Suhendri dan Tuti Mardalena. 2013. Pengaruh Metode Pembelajaran Problem Solving terhadap Hasil Belajar Matematika Ditinjau dari Kemandirian Belajar. Jurnal Formatif, 3(2):105-114.

Haris, Mujiman. 2011. Manajemen Pelatihan Berbasis Belajar Mandiri. Yogyakarta: Pustaka Pelajar.

Imam Mashuri. 2012. Pengaruh Pembelajaran Berbasis Masalah dan Inkuiri Ditinjau dari Kemandirian Belajar Siswa Kelas X SMA Negeri Kabupaten Blora. JMEE Volume II Nomor 1, (file:///C:/Users/user\%20only/Downloads/imam\%20mashuri.pdf). di unduh pada hari Selasa pukul $14.00 \mathrm{WIB}$.

Isriani hardini dan puspitasari. 2012. Strategi Pembelajaran Terpadu. Yogyakarta : Familya. Jumanta Hamdayama. 2014. Model dan Metode Pembelajaran Kreatif dan Berkarakter. Bogor. Ghalia Indonesia.

Kompri. 2015. Manajemen Pendidikan (Komponen-Komponen Elementer Kemajuan Sekolah). Yogyakarya: Ar-Ruzz Media.

Nidya Damayanti. 2012. Panduan Bimbingan Konseling. Yogyakarta: Araska.

Nor Asiyah. 2012, "Peranan Layanan Bimbingan Kelompok Dalam Meningkatkan Kemandirian Belajar Siswa Kelas VII MTS NU Miftahul Huda 02 Piji Bakaran Tahun Pelajaran 2011/2012" (Online),

Prayitno, dan Erman Amti. 2013. Dasar-Dasar Bimbingan dan Konseling. Jakarta: Rineka Cipta

Putu Nopi Sayondari. 2014. Penerapan Bimbingan Kelompok Dengan Teknik Diskusi Kelompok Untuk Meningkatkan Rasa Percaya Diri Siswa Kelas Viii E Smp Negeri 3 Singaraja Tahun Pelajaran 2013/2014. -journal Undiksa Jurusan Bimbingan Konseling Volume: 2 No 1. file:///C:/Users/user\%20only/Downloads/35-3880-1-SM.pdf. di unduh pada hari Selasa pukul 13.50 WIB.

Rostina Sundayana. 2016. Kaitan antara Gaya Belajar, Kemandirian Belajar, dan Kemampuan Pemecahan Masalah Siswa SMP dalam Pelajaran Matematika. STKIP Garut. Jurnal "Mosharafa", Volume 5, Nomor 2, Mei $2016 \quad 75$ ISSN 20864280. (file://C:/Users/user\%20only/Downloads/Rostina.pdf). di unduh pada hari Selasa pukul 13.50 WIB.

Raden Sudarwo, dkk. 2018. Pengaruh Sarana Belajar dan Motivasi Belajar Terhadap Kemandirian Belajar Mahasiswa (Studi Empiris Pada Mahasiswa Beasiswa Bidikmisi UPBJJ-UT Ternate). Jurnal Pendidikan, Volume 19, Nomor 2, 68-83. (http://jurnal.ut.ac.id/index.php/JP/article/view/701/759). di unduh pada hari Sabtu, 05 Juli 2019 pukul 13.15.

Rita dan Arfatin. 2016. Pengaruh Kemandirian Belajar dan Perhatian Orang Tua Terhadap Prestasi Belajar Matematika. Jurnal Formatif 6 (1). 73-84 ISSN: 2088-351X.

Sugiyono, 2013. Metode Penelitian Kuantitatif, Kualitatif, dan R\&D. Bandung: Alfabeta. 
2016. Metode Penelitian Kuantitatif, Kualitatif, dan R\&D. Edisi Revisi. Bandung: Alfabeta.

Suharsimi Arikunto. 2010. Prosedur Penelitian Suatu Pendekatan Praktik. Jakarta: Rineka Cipta. . 2013. Prosedur Penelitian Suatu Pendekatan Praktik. Jakarta: PT.Rineka Cipta.

Sunarto dan Agung Hartono. 2008. Perkembangan Peserta Didik.Jakarta: PT Rajagrafindo Persada

Sunarti dan Selly Rahmawati. 2013. Pendidikan dalam Kurikulum 2013. Yogyakarta: C.V Andi Offset.

Tatiek Romlah. 2006. Teori dan Praktik Bimbingan Kelompok. Malang: UM

Tohirin. 2013. Bimbingan dan Konseling di Sejokah dan Madrasah (Berbasis Integrasi). Jakarta: Rajawali Pers

Undang-undang Nomor 20 Tahun 2003 Tentang Sistem Pendidikan Nasional. Jakarta: Departemen Pendidikan Nasional.

Winkel. dan Sri Hastuti. 2013. Bimbingan dan Konseling di Institiusi Pendidikan.Yogyakarta: Media Abadi. 